資料

\title{
アルミナ磁器, ベリリア磁器†
}

\section{1. アルミナ磁器}

アルミナ磁器は1931 件, ドイッにおいてジンターュ ルンドとして発衣され，熟せんがい子に利用されて以 来, その特性に注:日され, 酸化物セラミックのうちでも 広く開発された材料の一つである. アルミナ磁器は $\alpha-$ $\mathrm{Al}_{2} \mathrm{O}_{3}$ を原料として, 微粉砕, 调整, 成形工程を経て, $1,400 \sim 1,800^{\circ} \mathrm{C}$ で焼成して，ち密な焼結体としたもの でコランダム結昆を主としてなり，80〜100\%近くの $\mathrm{Al}_{2} \mathrm{O}_{3}$ を含んでいる.

\section{1. アルミナ磁器の原料}

一般に使用されている精製アルミナの原料は, ボーキ サイトをアルカリで処理し，水酸化アルミニウムを作り これを $1200 \sim 1400^{\circ} \mathrm{C}$ で仮焼して， $\alpha \mathrm{Al}_{2} \mathrm{O}_{3}$ とするいわ ゆるバイヤー法によるものが多い，バイヤ一法で得られ たアルミナ原料は，0.3〜0.5\%のアルカリ成分を含んで 扣り, 電'依絶縁性を向上するために, アルカリ成分を除 去したローソーダアルミナが多く採用されている. また 最近では, 高純度アルミナ原料（99.9％以上）を得る

表 1 高純度アルミナ原料特性

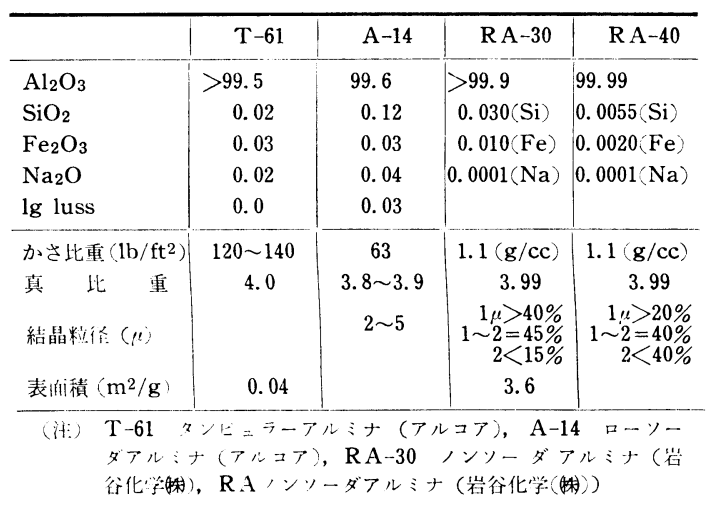

* Alumina Porcelain, Beryllia Porcelain.

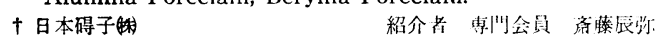

\section{松 井峻*}

ために, 出発原料を高純度金属アルミニウムより化学処 理によって, $\alpha \mathrm{Al}_{2} \mathrm{O}_{3}$ としたノンソーダーで, 焼結性の 良いアルミナ原料も市敗されている（表 1).

\section{2. アルミナ磁器の製法}

原料を微粉砕，不純物除去ののち，一般に焼結促進斉 として, $\mathrm{MgO}, \mathrm{SiO}_{2}, \mathrm{CaO}, \mathrm{MnO}_{2}, \mathrm{TiO}_{2}$ などが添加さ れ, 均一に混合後, 各種の成形方法により作ることがで きる。

\section{1 プレス 成 形}

水分量によりドライブレスと, ウェットプレスに大別 できる，ブレス型としては，超硬合金やダイス鋼を用い て，スブレードライヤーなどで造粒された粉末を用い て，寸法粘度の良好な成形体が得ることができる。

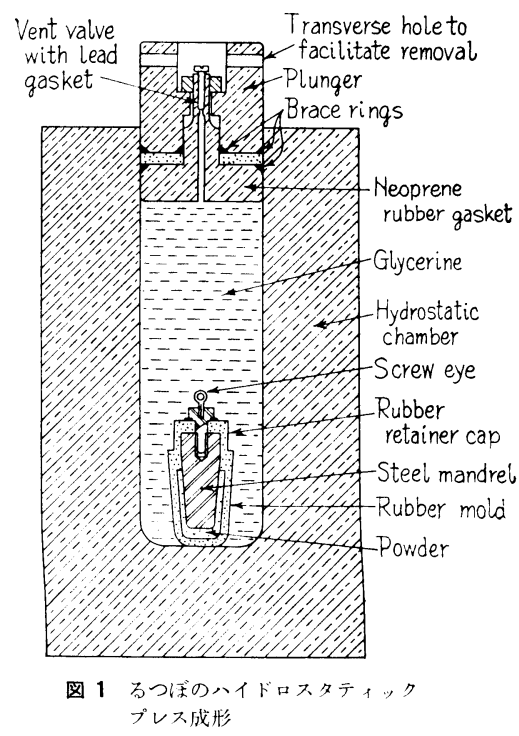

\section{2 ハイドロスタティックプレス}

スプレードライヤーなどで造粒された流動性のよい原 料粉末をゴム型に充てんし, 加圧容器の液体中に型とと 
もに入れて，この濉体に地力を加えると：゙ム型の外か ら粉末に対して, 全方向から加压されるはで, 均一な成 形体が得られる。図1はるつぼのハイドロスタティック プレスの状態をバす.

\section{3 ホットプレス成形}

黑鉛の成形体に原料粉末を老てんして，高病波加熱に より昇温し焼結と成形を间侍に行なう。一般の焼成より 焼結温度が低くてすみ，䓡牌间加熱なために焼結体の絬 晶成長を防止し, 高密度化ができて高耖度な做器が得ら れる。

\section{4 流 ᄂ 込 み成形}

原料を樂濁状のスリッフにして, せっこう型に流し込 み, せっこ5目体の吸水性を利肌して落燥され, 成形体 を得る。

\section{5 押し出し成形}

有機物の絬合剂を添加した四朔!性の坏土を，ダイスを 通して丸杵や円简などを成形する。

\section{6 焼成}

以上の各種の方法で成形さ机た牛素地は, 䓵燥後ガス 炉，または電知㭁iで1, $400 \sim 1,800^{\circ} \mathrm{C}$ で焼絬される，焼 結条作はアルミナ䂭器の純度や原料の精度, 添加剂の種 類，焼成ふんい爻などにより是なり，焼絬の条件により 再結目粒径やその他の持性にも省しく影響される.

\section{7 研摩}

寸法精度がきびしいものや，特殊な形状の製品に関し ては, 㨁成後に研摩加厂する。 アルミナ傸器は硬度が高 い（モース 9 ) ため，研磨はダイヤモンドと们による加 工が主体で，その他超音波加厂法も実用化されるに至 りまた最近では、レーザによる新加工法も開発されて いる.しかし，いずれの加、法にしても焼絬体の加工：

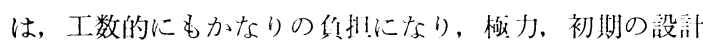
段階において, 寸法公差, 形状などを考忍する必要があ る.

\section{8 アルミナ磁器のメタライズおよびメタルミール}

七ラミックは忺化温度が高いので, 金風との封着に関 しては, ガラスシールの場合とは異次り独自な封看技術 が必要で, 以前から種々の力法が研究開発されてきた. 現在, 主として奏用化されている方法としては, 金属粉 末焼結法, 活性金属法があり, また近作, 高温がラス法

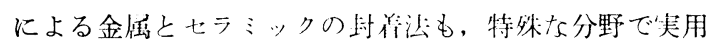
化されている。

\section{（1）金属粉末焼結法}

第二次田界大戦中，ドイッのテレフンケン社の $\mathrm{H}$. Pulfrih によって開発され火猜化された方法で,一般 にテレフンケン法1)，あるいはモりブデン金牌化法とい

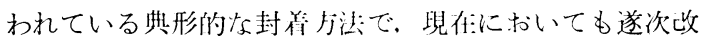
良を加六広く採用されている。
このす法は金属材料として, Mo 微粉末に $\mathrm{Fe}, \mathrm{Ni}$ 粉 末を添加されたものが利用され，その後 $\mathrm{Ti}, \mathrm{Mn}$ など の活性な金属を添加された Mo-Mn'2) 法に改良され, さ らには Mo-Mn 粉末に七ラミックと反応をしやすくす るため, ガラス粉末 ${ }^{3)}$ や七ラミックの微粉末4) を添加し た多種の組成が遂次研究されている．この金属化の方法 は，上記のMoを主とした金属微粉末に有機物のバイン ダーと溶剂を添加し，ヘースト状にしたものを磁器の表 面に印刷, スンレー, 浚治などの方法で塗布し, 還元気 中で $1,200 \sim 1,700^{\circ} \mathrm{C}$ の高温にて筑成して磁器と反応さ せ，その後 $\mathrm{Ni}$ めっきなどをして，金属とろら付け，あ るいははんだ付けにて封痽される方法である。

\section{(2) 活性金属 法}

この方法は, $\mathrm{Ti}$ あるいは $\mathrm{Zr}$ の水素化合物 $\left(\mathrm{TiH}_{2}\right.$, $\mathrm{ZrH}_{2}$ ）を用いる方法5)と， $\mathrm{Ti}$ あるいは $\mathrm{Zr}$ の金属を使 ら万法6が饬るが，いずれも $\mathrm{Ti}$ や $\mathrm{Zr}$ のよらな非常に 活性の強い金属亡ろう材を用いる点で同様であるので, 活性金属法と呼涊孔ている.

前者は 1947 价:ニ, GE 社の R. J., Bondely が発表し たもので，Ti あるいは $\mathrm{Zr}$ のハイドライドの微粉末を テレフンケン法之大体同じ操作でセラミックに塗布し, 銀万らとともに金属と接着させて真空, あるいは不活性 ガス中で $900 \sim 1, \mathrm{C} 00^{\circ} \mathrm{C}$ に加熱すると, $\mathrm{Ti}, \mathrm{Zr}$ のハイ ドライドは分解し $\mathrm{Ti}, \mathrm{Zr}$ てとなり, ろら材と活性合金 ができて, 磁器の金属化と, 金属とのろう付けが 1 回の 操作で同時に行なわれる.

後者の $\mathrm{Ti}$ 金属を用いる方法はハイドライド法よりも 進歩した方法で, 1949 年MIT の Pearsall と, Zingeser の発表によるもので, この方法は, 両面銀ろらではさま れた Ti の板を七ラミックと封着金属との間に置き, 高 真空中で $800 \sim 1,000^{\circ} \mathrm{C}$ で加熱融着させる方法である. シルバニア社から発表された BT-Ti, Cored Wire, な どが市販されて新り，七ラミックと金属の封着が全く 1 问の操作ででき，これが奏用的な最初の方法ともいえ， る.

1956 年にはさらに改良され, Beggs がTi-Ni法7を発 㠿している.これらの活性金属法は, テレフンケン法に 比べて, 1 回の加熱操作でセラミックのメタライズと金 属封着が同時に完了するという点では有利であるが，高： 真空や加熱時の接着圧力, 材質やその表面状態など多く の影響因子があり, 量産的な立場からもむずかしい問題 点が残されている.

\section{(3) 高温ガラス法}

アルミナ磁器の純度が增すにつれて, テレフンケン法 では人タライズの接着強度が低下し, 高純度アルミナ磁 器に対しては良好な揬着強度が得られていない.しかし 最近，七ラミックと金属を直接封着できる高温ガラス法 
表 2 行種乃ルミナ磁器の特性

\begin{tabular}{|c|c|c|c|c|c|c|c|c|}
\hline 物 & 珄 & 位 & $85 \% \mathrm{Al}_{2} \mathrm{O}_{3}$ & $90 \% \mathrm{Al}_{2} \mathrm{O}_{3}$ & $94 \% \mathrm{Al}_{2} \mathrm{O}_{3}$ & $96 \% \mathrm{Al}_{2} \mathrm{O}_{3}$ & $99 \% \mathrm{Al}_{2} \mathrm{O}_{3}$ & $99.9 \% \mathrm{Al}_{2} \mathrm{O}_{3}$ \\
\hline 比 & 重 & & $3.38 \sim 3.44$ & $3.53 \sim 3.58$ & $3.58 \sim 3.70$ & $3.68 \sim 3.74$ & $3.80 \sim 3.90$ & $3.96 \sim 3.99$ \\
\hline 吸水率 & & & ts $\quad$ L & 应 & な & 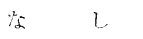 & な & な \\
\hline 気 孔 率 & & & $\begin{array}{c}\text { 気密 性 } \\
\text { 它 }\end{array}$ & 间左 & 同左 & [ii] 光 & 间左 & 同当 \\
\hline 抗折強度 & 度 & $\begin{array}{r}\mathrm{kg} / \mathrm{mm}^{2} 20^{\circ} \mathrm{C} \\
1100^{\circ} \mathrm{C}\end{array}$ & $\begin{aligned} 28 & \sim 32 \\
7 & \sim 10\end{aligned}$ & $\begin{array}{r}30 \sim 34 \\
-\end{array}$ & $\begin{array}{l}31 \sim 35 \\
10 \sim 14\end{array}$ & $\begin{array}{l}33 \sim 37 \\
15 \sim 18\end{array}$ & $\begin{array}{l}33 \sim 42 \\
16 \sim 20\end{array}$ & $\begin{array}{l}80 \\
-\end{array}$ \\
\hline 医縮強度 & 度 & $\mathrm{kg} / \mathrm{mm}^{2}$ & $>179$ & & $>210$ & $>210$ & $>210$ & 455 \\
\hline 引垠倠 度 & 莨 & $\mathrm{kg} / \mathrm{mm}^{2} 20^{\circ} \mathrm{C}$ & 13 & - & 19 & 20 & 24 & 42 \\
\hline 硬度 & 度 & ロックウェル $45 \mathrm{~N}$ & 75 & 79 & 78 & 78 & 80 & $90 \sim 91$ \\
\hline 弾 性 率 & & $\mathrm{kg} / \mathrm{mm}^{2}$ & 22500 & 27300 & 2800 & 29500 & 35200 & 39200 \\
\hline 最㴼使用温㦄 & & ${ }^{\circ} \mathrm{C}$ & 1400 & 1500 & 1700 & 1700 & 1725 & \\
\hline 此 & 熱 & $\mathrm{kcal} / \mathrm{kg} /{ }^{\circ} \mathrm{C}$ & 0.18 & & 0.19 & 0.19 & 0.20 & 0.21 \\
\hline 熱伀渞率 & & $\mathrm{Cal} / \mathrm{cm} / \mathrm{sec} /{ }^{\circ} \mathrm{C} \mathrm{CO}{ }^{\circ} \mathrm{C}$ & 0.035 & 0.040 & 0.043 & 0.043 & 0.43 & 0.070 \\
\hline \multirow{6}{*}{\multicolumn{2}{|c|}{ 熱影浸保数 }} & $\begin{array}{r}400^{\circ} \mathrm{C} \\
\times 10^{-6} /{ }^{\circ} \mathrm{C}\end{array}$ & 0.016 & 0.012 & 0.017 & 0.017 & 0.028 & 0.031 \\
\hline & & $-200 \sim+25^{\circ} \mathrm{C}$ & 2.3 & 3.4 & 3.4 & 3.4 & 3.4 & 3.6 \\
\hline & & $25 \sim 200^{\circ} \mathrm{C}$ & 5.4 & 6.1 & 6.3 & 6.0 & 6.0 & 6.8 \\
\hline & & $200 \sim 500^{\circ} \mathrm{C}$ & 6.8 & 7.6 & 7.7 & 8.2 & 8.2 & 8. 0 \\
\hline & & $500 \sim 800^{\circ} \mathrm{C}$ & 8.3 & 8.9 & 8.5 & 8.9 & 9.3 & 8.9 \\
\hline & & $800 \sim 1200^{\circ} \mathrm{C}$ & 9.0 & 9.8 & 9.2 & 9.1 & 10.0 & 9.7 \\
\hline \multirow{3}{*}{\multicolumn{2}{|c|}{ 体積阔有抵抗 }} & $\Omega \mathrm{cm}$ & $>10^{14}$ & $>10^{14}$ & $>10^{14}$ & $>10^{14}$ & $>1014$ & $>10^{15}$ \\
\hline & & 300 & $4.6 \times 10^{10}$ & $1.4 \times 10^{11}$ & $9.0 \times 10^{11}$ & $3.1 \times 10^{11}$ & $1.0 \times 10^{13}$ & $1.0 \times 10^{15}$ \\
\hline & & 1000 & - & $8.6 \times 10^{5}$ & $5.0 \times 10^{5}$ & $5.0 \times 10^{6}$ & $2.0 \times 10^{6}$ & $1.1 \times 10^{7}$ \\
\hline \multicolumn{2}{|l|}{ Te $\cdot$ Value } & ${ }^{\circ} \mathrm{C}$ & 850 & 960 & 950 & 1000 & 1050 & 1170 \\
\hline \multirow[t]{2}{*}{ 梓 } & 率 & $1 \mathrm{KC}\left(25^{\circ} \mathrm{C}\right)$ & 8.2 & 8.8 & 8.9 & 9.0 & 9.5 & - \\
\hline & & $1 \mathrm{MC}\left(25^{\circ} \mathrm{C}\right)$ & 8.2 & 8.8 & 8.9 & 9.0 & 9.5 & - \\
\hline \multirow{2}{*}{\multicolumn{2}{|c|}{ 餧饥損失 }} & $1 \mathrm{KC}$ & 0.011 & 0.005 & 0.002 & 0.010 & 0.040 & - \\
\hline & & $1 \mathrm{MC}$ & 0.007 & 0.004 & 0.001 & 0.001 & 0.002 & - \\
\hline
\end{tabular}

が開発されてきたこの方法は $1,200^{\circ} \mathrm{C}$ 以上の融点を あつ酸化物ガラス, たとえば $\mathrm{Al}_{2} \mathrm{O}_{3}-\mathrm{CaO}-\mathrm{MgO}-\mathrm{SiO}_{2}$ 系

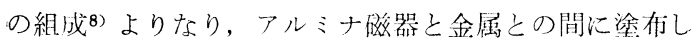
て, 酸化物の融点より約 $50^{\circ} \mathrm{C}$ 高い温度で加熱融着する ことにより，良好な接着が得られることが明らかにされ ている.

\section{3. アルミナ磁器の特性}

アルミナ磁器の性質は, アルミナ純度, 原料, 成形方 法焼成条件に上り性能は変わるが，一般的な特性として (1) 強度が高く，耐摩耗性にすぐれている. (2) 歫化高温

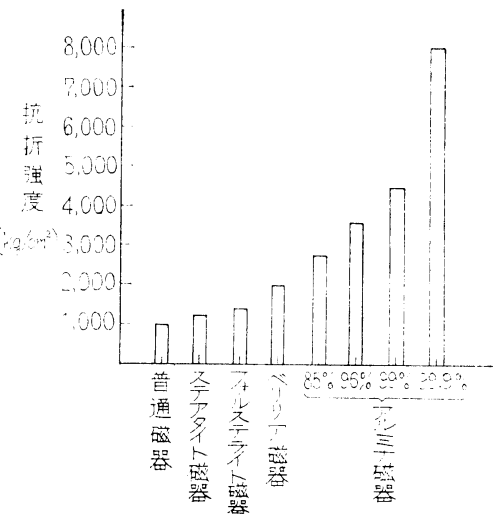

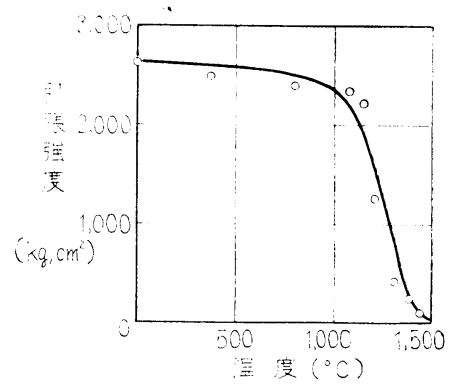

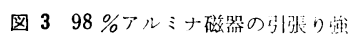
隹之温度特性

が高く，熱伝導が比較的良いため耐熱衝慗性がよい。(3) 化学耐食性がすぐれている（4）高温に括ける電㸚絶縁 性や高周波特性がすぐれている。などがあげられる（表 2 ).

\section{1 機械的, 熱的性質}

アルミナ湫器は, セラミック材料の中でも機械的強度 がすぐれ，アルミナ含有量が增すにつれて品度が向上す る（図２），また温度が上昇するに従って，ての強度は 少化する傾向を亦すが， $1,000^{\circ} \mathrm{C}$ では法とんど変化が ない（図 3)。純アルミナの融点は $2,040^{\circ} \mathrm{C}$ で, 耐熱 度は高く熱伝浮畒も比較的大きいため, 熱衝撃に対して 西強い材犋とい光る。

図 2 各種磁器の機械的话度: 


\section{2 電 気 的 性 質}

アルミナ磁器は, 高温においても高い絶縁性を有し (図 4 ), またアルミナ磁器中のアルカリ含有量により 固有抵抗が異なる（図 5 ). またた誘電損失が小さく高周 波特性もすぐれており, 電子管の外囲器として適してい る(図 6).

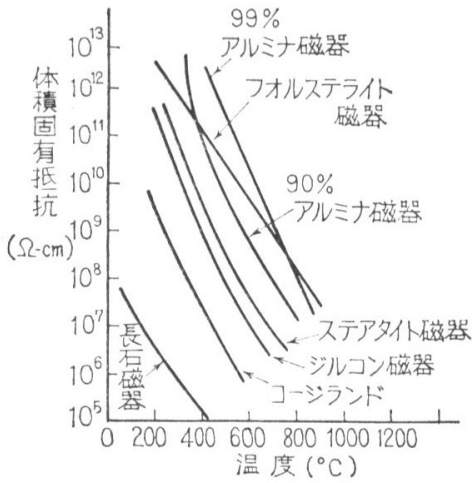

図 4 各種磁器の体積固有抵抗

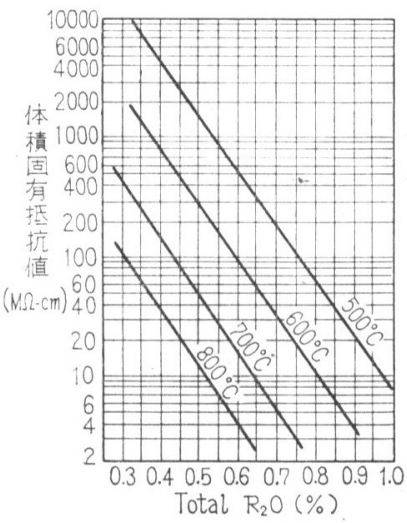

図 $590 \%$ \%ルミナ磁器のアルカリ含有显 と体積固有抵抗
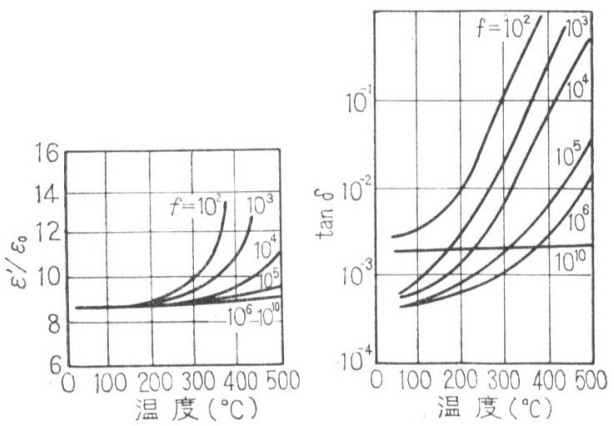

图 $695 \%$ ルミナ磁器のと, $\tan \delta$ の温度周波 数特性 (PB-33375 by W. B. Westphd)

\section{3 化 学 的 性 質}

アルミナ磁器は, ふっ酸, りん酸以外に対しては化学 的に安定な材質で，高温に拈いてカーボン，水素などの
表 3 フルミナ磁器の耐食性 10 )

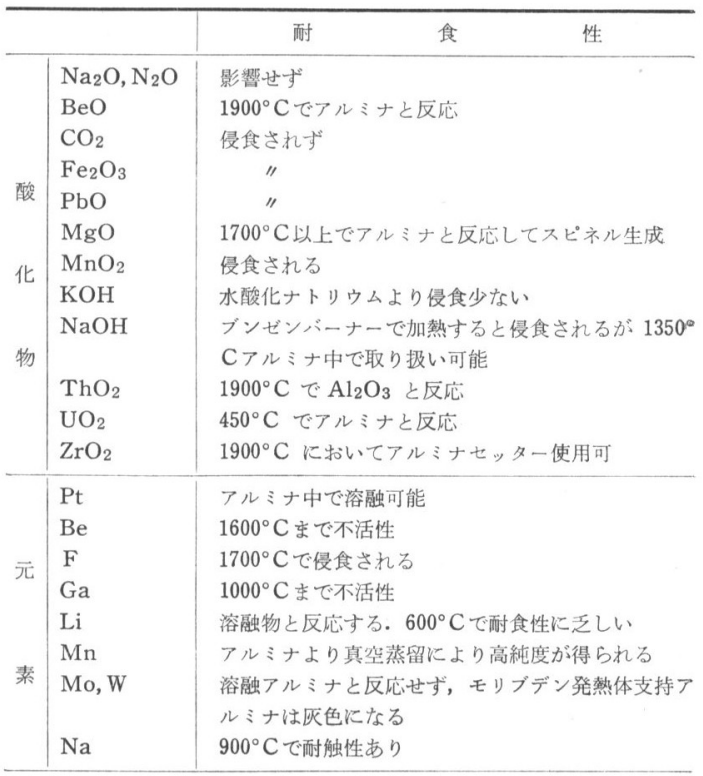

還元気中でも安定している. アルミナ磁器の耐食性につ いては表 3 に示した.

\section{4 アルミナ磁器の微構造}

アルミナ磁器は $\alpha-\mathrm{Al}_{2} \mathrm{O}_{3}$ とガラス相よりなり, 結晶 粒径は, 数 $\mu$ から数十 $\mu$ 以上の大きな結晶を持つ磁器 もある. 結晶の大ささは添加剂の種類や量, 原料粉末, 製造条件などにより左右され，その結果，焼結された磁 器の特性も異なってくる (図 7). 磁器中に存在する気 孔は, 機械的, 熱的, 電気的に悪い影響を与え, 最近で

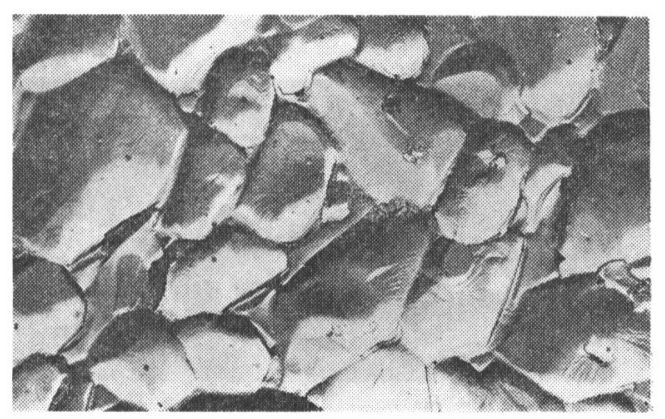

图 $796 \% \mathrm{Al}_{2} \mathrm{O}_{3}$ 磁器の電顕写真 $(\times 8,000)$

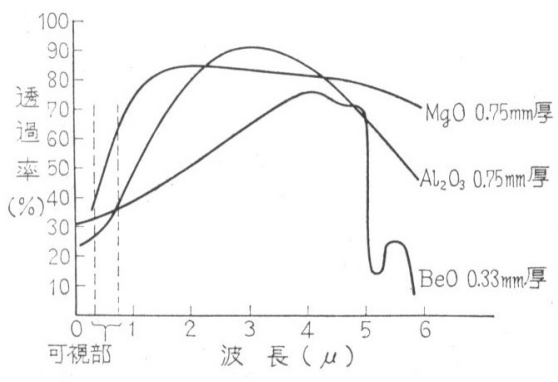

図 $8 \mathrm{Al}_{2} \mathrm{O}_{3}, \mathrm{BeO}, \mathrm{MgO}$ 透光性磁器の光透過率

Vol.53 No.4 
は高純度のアルミナ微粉原料を用いて, 特殊らんい気焼 成により, 気孔を含まない透光性アルミナが開発され, 高純度酸化物透明体として, 透明ベリリア, 透明マグネ シアも開発されている. 各種酸化物の光透過性について 示し (図 8), アルミナ, ベリリア, マグネシア透光性 磁器の特性を比較した (表 4 ).

表 4 透光性磁器の特性

\begin{tabular}{|c|c|c|c|}
\hline & 透明アルミナ & 唀明ベリリア & 透明マグネンフ \\
\hline $\begin{array}{l}\text { 光 透 過 性 } \\
\text { (視光措散過) }\end{array}$ & $90 \%$ 以上 & $90 \%$ 以上 & $90 \%$ 以上 \\
\hline $\begin{array}{l}\text { 気 }{ }^{\text {密 }} \text { 性 } \\
\text { ctor }\end{array}$ & $\begin{array}{r}10^{-9} \mathrm{cc} / \mathrm{sec} \\
\text { 以下 }\end{array}$ & $\begin{array}{r}10^{-9} \mathrm{cc} / \mathrm{sec} \\
\text { 以下 }\end{array}$ & $\begin{array}{c}10^{-9} \mathrm{cc} / \mathrm{sec} \\
\text { 以下 }\end{array}$ \\
\hline $\begin{array}{l}\text { 熱 膨 張係数 } \\
\left(20 \sim 1000^{\circ} \mathrm{C}\right)^{-1} \times \\
10^{-6}\end{array}$ & 8.40 & 8.90 & 14. 20 \\
\hline 耐熱衝繋性 & 優 & 秀 & 良 \\
\hline 純 & $\begin{array}{l}\mathrm{Al}_{2} \mathrm{O}_{3} \\
99 \% \text { 以上 }\end{array}$ & $\begin{array}{l}\mathrm{BeO} \\
99.5 \% \text { 以上 }\end{array}$ & $\begin{array}{l}\mathrm{MgO} \\
98 \% \text { 以上 }\end{array}$ \\
\hline
\end{tabular}

\section{4. アルミナ磁器の用途}

アルミナ磁器の用途は, 高温での絶縁抵抗が大きいた

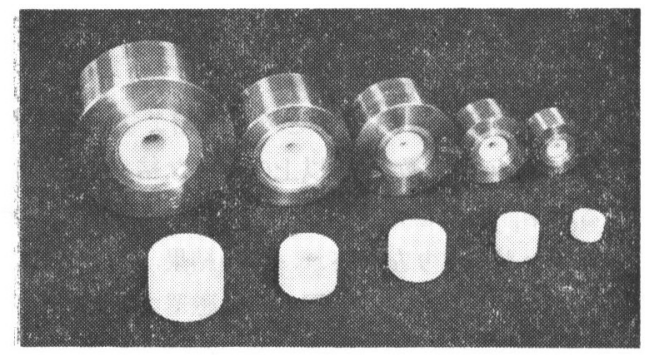

図 9 アルミナ磁器セラミックダイス

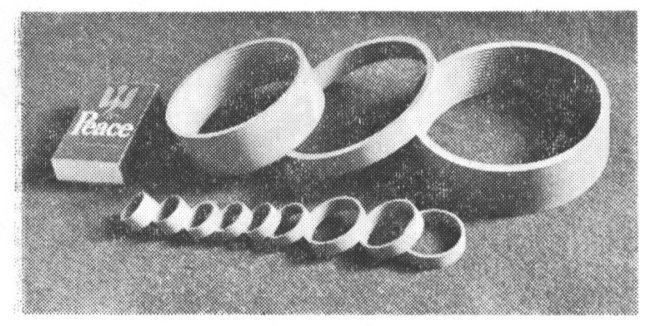

図 10 アルミナ磁器電子管外用器

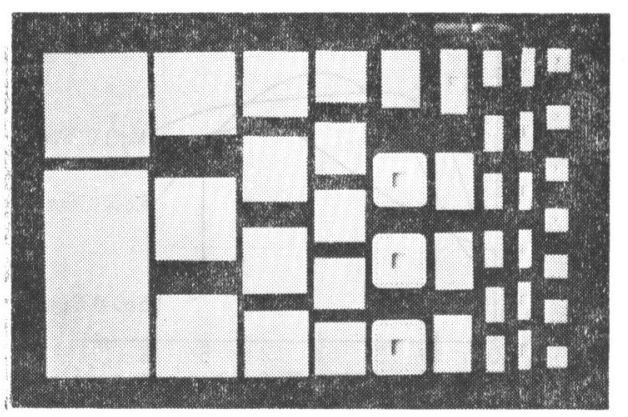

図11 アルミナ磁器 IC 用基板

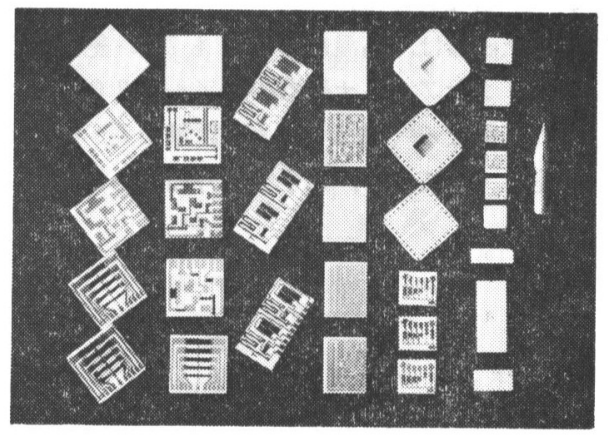

図 12 フルミナ磁器厚膜 IC 回路基板

め点火せんがい子に古くから利用され，機械的強度や耐 摩耗性がすぐれていることから, 七ラミックダイスや, 摺動環, ブランジャシャフトなどの各種耐摩耗磁器とし て広く利用されている(図 9). 耐熱材料としては, 高温での炉芯管や保護管にも適し, 高周波絶縁材料とし て電子管外用器（図 10）や，最近では集積回路用基板 にも数多く使われている（図 11，12）. 特殊な用途とし て, GE 社で開発された透明アルミナ磁器は, 耐熱性, 耐食性, 高強度などの点から, 高圧ナトリウムランプの 発光管として注目され，国内でも，アルミナのほかにべ リリア, マグネシアなどの透光性磁器の開発が進み, セ ラミックの新しい応用分野として, 大きな期待がもたれ ている(図 13).

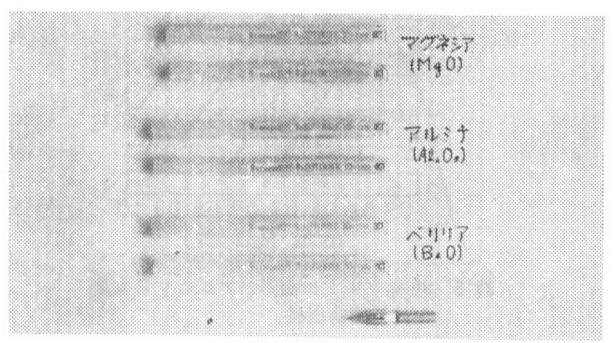

(a)

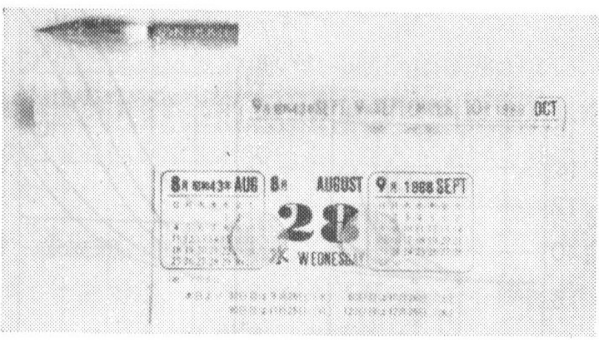

(b)

図 13 各種酸化物透過磁器

(a) 透明七ラミック・ペプ (b) 透明アルミナ

\section{II ベリリア磁器}

ベリリア磁器は, ニューセラミックの中でもアルミナ 磁器と同じように, すぐれた電気時性とセラミックとし 
ては最良の熱伝導率をもち，また高耐熱性（融点 2550 ${ }^{\circ} \mathrm{C}$ ) と核特性のよいことから，電子工業用途をはじめ として, 電子力工業, 宇宙工学に至るまでの各種の用途 に広く採用されるようになってきた，海外ではアメリカ で特に伸展し，フランス，イギリス，日本に拈いてもそ の用途が急速に伸びつつある.

\section{1. ベリリア磁器の製造工程}

ベリリア磁器の製造方法は，アルミナ磁器と注ぽ同様 な葖業的手法を用いて作ることができる，原料である酸 化ベリリウム $(\mathrm{BeO})$ は, 主として緑柱石 (Beryl $3 \mathrm{Be}$ $\left.\mathrm{O}, \mathrm{Al}_{2} \mathrm{O}_{3}, 6 \mathrm{SiO}_{2}\right)$ を原料鉱石として $\mathrm{BeO}$ 成分を抽出精 製される. 緑柱石から酸化べリリウムを抽出するには， 種々の方法があるが, 現在, 工業的にはふっ化物法と硫

表 5 高純度 $\mathrm{BeO}$ 粉末の不純物分析值 (ppm)

\begin{tabular}{c|c|c}
\hline 不純物元素 & $\mathrm{CF}-\mathrm{BeO}(\mathrm{NGK})$ & UOX-BeO (Brush) \\
\hline $\mathrm{Si}$ & 100 & 100 \\
$\mathrm{Al}$ & 10 & 100 \\
$\mathrm{Fe}$ & 20 & 20 \\
$\mathrm{Na}$ & 50 & 50 \\
$\mathrm{Ca}$ & 100 & 50 \\
$\mathrm{Mg}$ & 20 & 50 \\
$\mathrm{Ni}$ & 20 & 20 \\
$\mathrm{Cu}$ & 5 & 5 \\
$\mathrm{Cr}$ & 10 & 10 \\
$\mathrm{Mn}$ & 10 & 10 \\
$\mathrm{Co}$ & 3 & 5 \\
$\mathrm{Cd}$ & 1 & 2 \\
$\mathrm{~B}$ & 0.5 & 3 \\
$\mathrm{Li}$ & 0.5 & 1 \\
\hline
\end{tabular}

酸法が広く用いられている. これらの方法より, いずれ 子水酸化ベリリウム $\left(\mathrm{Be}(\mathrm{OH})_{2}\right)$ が得られ, これを熱分 解して酸化ベリリウムとする. 高純度べリリア原料は, 水酸化ベリリウムに種々の処理を加え, $99.5 \sim 99.8 \%$ の 高純度 $\mathrm{BeO}$ 粉末を精製することがでさる（表 5). へ リリア磁器の成形方法は, 形状, 個数, 用途によって決 められるが, プレス成形, 押し出し成形, 流し込み成 形, 八イドロスタティックプレス成形, ホットプレス成 形などが用いられている。焼成は電気炉またはガス炉 で $1,600^{\circ} \mathrm{C}$ 以上の高温焼成により，ち密な焼結体を得る ことができる(図 14). ベリリア磁器のメタライズおよ びメタルシールは, 一般にアルミナ磁器に採用されてい る. 金属粉末焼結法 (Mo-Mn 法)が適用でき, 還元気 中で $1,300 \sim 1,700^{\circ} \mathrm{C}$ で強固なメタライズドベリリア磁 器を得ることができる. そのメタライズ強度は, 純度,

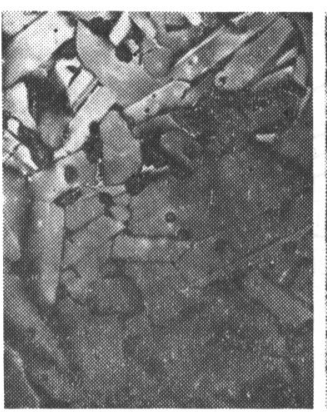

(a)

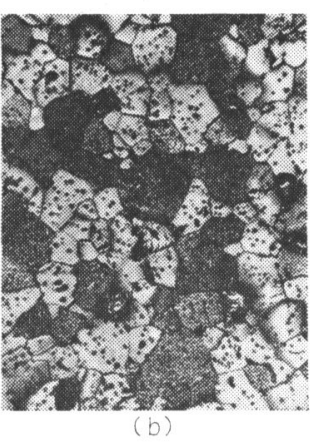

( b)
図 14 ベリリア磁器の顕微鏡写真

(a) $95 \% \mathrm{BeO}$ (b) $99,5 \%(\times 300) \mathrm{BeO}$

表 6 ペリリア磁器の諸特性

\begin{tabular}{|c|c|c|c|c|c|c|c|}
\hline & \multicolumn{3}{|c|}{ NGK } & \multicolumn{3}{|c|}{ Coors } & \multirow{2}{*}{$\begin{array}{c}\begin{array}{c}\text { National } \\
\text { Beryllia }\end{array} \\
99\end{array}$} \\
\hline & $\mathrm{K}-95$ & $\mathrm{~K}-99$ & $\mathrm{~K}-995$ & B D-96 & BD-98 & B D-995 & \\
\hline 度 $(\%)$ & 95 & 99 & 99.5 & 96 & 98 & 99.5 & 99 \\
\hline 色 & 白 & 白 & 色 & 色 & 色 & 白 & 白 \\
\hline 比 & 2.8 & 2.9 & 2.9 & 2.85 & 2.85 & 2.85 & - \\
\hline 率 & 0 & 0 & 0 & 0 & 0 & 0 & 0 \\
\hline さ $\left(\mathrm{kg} / \mathrm{cm}^{2}\right)$ & 1900 & 1900 & 1900 & 1750 & - & 2100 & 2100 \\
\hline さ (mohs) & 9 & 9 & 9 & - & 一 & - & - \\
\hline 熱伝導率 $\left(\mathrm{cal} /\right.$ 秒 $\left.\cdot{ }^{\circ} \mathrm{C} \cdot \mathrm{cm}\right) 20^{\circ} \mathrm{C}$ & 0.48 & 0.58 & 0.61 & - & 0.49 & 0.60 & 0.60 \\
\hline $100^{\circ} \mathrm{C}$ & 0.40 & 0.44 & 0.46 & - & - & $\begin{array}{r}0.45 \\
5.7\end{array}$ & - \\
\hline 熱 膨 張 係 数 $\quad\left(25 \sim 150^{\circ} \mathrm{C}\right)$ & 0.4 & 4.6 & 4.4 & 10.1 & 9.2 & $\left(25-200^{\circ} \mathrm{C}\right)$ & - \\
\hline$\left(150 \sim 400^{\circ} \mathrm{C}\right)$ & 8. 0 & 8.1 & 7.8 & $\left(25-1000^{\circ} \mathrm{C}\right)$ & $\left(25-1000^{\circ} \mathrm{C}\right)$ & $\left(200-\mathrm{S} 500^{\circ} \mathrm{C}\right)$ & 一 \\
\hline$\left(400 \sim 800^{\circ} \mathrm{C}\right)$ & 10.0 & 10.3 & 10.5 & - & - & $(500-800)$ & - \\
\hline 最高使 用 温度 $\left({ }^{\circ} \mathrm{C}\right)$ & 1800 & 2000 & 2000 & 1700 & 1800 & 1850 & 2200 \\
\hline.$\quad\left(100^{\circ} \mathrm{C}\right)$ & $10^{14}$ & $10^{15}$ & 1015 & - & - & - & - \\
\hline$\left(200^{\circ} \mathrm{C}\right)$ & 1012 & $10^{14}$ & 1015 & - & - & - & - \\
\hline$\left(300^{\circ} \mathrm{C}\right)$ & 1011 & $10^{13}$ & $10^{14}$ & 1015 & $10^{15}$ & $10^{15}$ & - \\
\hline$\left({ }^{\circ} \mathrm{C}\right)$ & 1000 & 1100 & 1200 & 1170 & 1220 & 1240 & - \\
\hline$(\mathrm{kV} / \mathrm{mm}) 50 \mathrm{~Hz}$ & 12 & 14 & 14 & 13 & 14 & 14 & 12 \\
\hline 率 $\varepsilon($ IMC) & 7.7 & 6.8 & 7.1 & 6.6 & 6.5 & 6.7 & 6.4 \\
\hline$(100 \mathrm{Mc})$ & 6.2 & 6.5 & 6.6 & - & - & - & - \\
\hline 誘 電 体 力 率 $\tan \delta(\mathrm{IMC})$ & 0.0007 & 0.0005 & 0.0002 & 0.0001 & 0.0001 & 0.0003 & 0.0006 \\
\hline$(100 \mathrm{Mc})$ & 0.0005 & 0.0001 & 0.0001 & - & - & - & - \\
\hline
\end{tabular}


結晶粒径, 添加風の種類や量比により影響される. ベリ リア磁器と金属との封着は，メタライズ後コバール，鉄 ニッケル合金， ニッケル，銅などの各種の金属とろう付 け，あるいははんだ付けで気密封止ができるが，各材料 の熱膨張やろら材，そして封着形態を十分考慮して設計 する必要がある。

\section{2. ベリリア器磁の特性}

各種ベリリア磁器の特性を（表 6）に示した.

\section{1 熱 的 性 質}

ペリリア磁器の熱伝導率は, 七ラミックの中では最も 大きく, アルミナ磁器の約 10 倍, マグネシア磁器の約 6 倍で，銀，銅，金に次いで大きく，金属アルミニウム

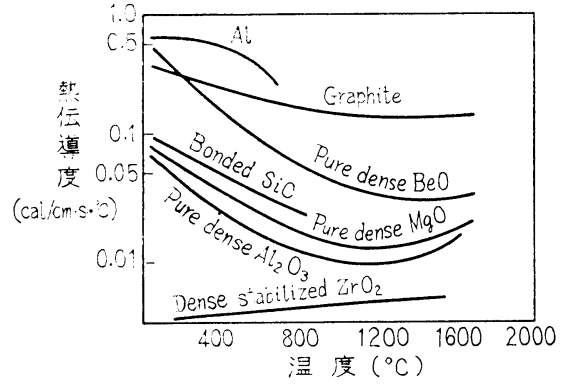

图 15 各唕セラミックスの熱伝導度

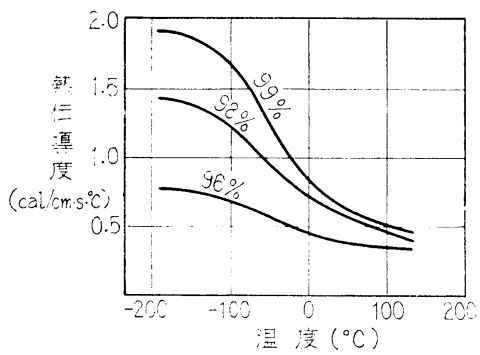

図 16 名種純度ベリリア磁器の熱伝導度:

よりも高い熱伝導率字示している（表 7 ）。高純度ベリ リア礘器の熱伝導率は, 常温に拈いて $0.63 \mathrm{cal} / \mathrm{sec} / \mathrm{cm}$ $/{ }^{\circ} \mathrm{C}$ であるが，温度の上昇とともに低下する傾向を示 す（図 15)。また純度が低下することにより大きく変化

表 7 络種金属於よび磁器の熱伝道率

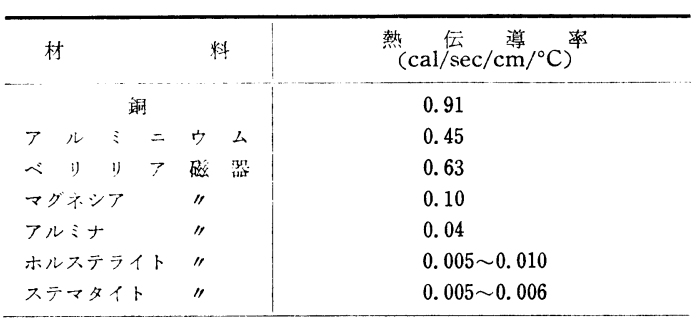

し，高純度ほど熱伝導は良好である（図 16）。高熱伀導 率をもつベリリア磁器の耐熱衝撃係数は, 酸化物中磁器 中では最もすぐれた高い値いを持っている（表 8 ).

表 8 各種材料の熱衝撃係数

\begin{tabular}{|c|c|c|c|c|}
\hline \multirow{3}{*}{ 材 } & \multirow{3}{*}{ 料 } & \multirow{2}{*}{\multicolumn{3}{|c|}{$\begin{array}{r}\text { 熱衝撃係数 } \gamma=\mathrm{K} \delta(1-\nu) / \mathrm{E} \cdot a \\
\mathrm{cal} \cdot \mathrm{cm}^{-2} \cdot \text { 秒 }-1 \mathrm{~cm} \cdot{ }^{\circ} \mathrm{C}-1\end{array}$}} \\
\hline & & & & \\
\hline & & $100^{\circ} \mathrm{C}$ & $400^{\circ} \mathrm{C}$ & $1000^{\circ} \mathrm{C}$ \\
\hline \multirow{5}{*}{$\begin{array}{l}\text { 酸 } \\
\text { 货 } \\
\text { 礠 } \\
\text { 器 }\end{array}$} & $\mathrm{Al}_{1} \mathrm{O}_{3}$ & 3.4 & 1.5 & 0.7 \\
\hline & $\mathrm{BeO}$ & 29.4 & 12.0 & 2.6 \\
\hline & $\mathrm{MgO}$ & 2.9 & 1.3 & 0.58 \\
\hline & $\mathrm{ThO}_{2}$ & 1.5 & 0.87 & 0.5 \\
\hline & $\mathrm{ZrO}_{2}$ (安定化) & 0.44 & 0.45 & 0.51 \\
\hline \multirow{5}{*}{$\begin{array}{l}\text { 七 } \\
\text { 亏 } \\
\vdots \\
y \\
y \\
\text { ス }\end{array}$} & Porcerain & 0.68 & 0.70 & 0.75 \\
\hline & Zircon & 3.4 & 2.5 & 2.1 \\
\hline & $\mathrm{TiO}_{2}\left(3.95 \mathrm{~g} / \mathrm{cm}^{2}\right)$ & 0.58 & 0.42 & - \\
\hline & $\mathrm{TiO}_{2}\left(4.1 \mathrm{~g} / \mathrm{cm}^{2}\right)$ & 0.67 & 0.56 & 0.50 \\
\hline & $\mathrm{TiO}_{2}$ (ポーシス) & 0.62 & 0.49 & - \\
\hline \multirow{2}{*}{$\begin{array}{l}\text { ガラス } \\
\text { そのはか }\end{array}$} & fvsed $\mathrm{SiO}_{2}$ & 11.4 & 13.5 & - \\
\hline & グラファイト & 310.0 & 197.0 & 109.0 \\
\hline
\end{tabular}

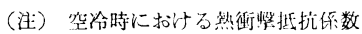

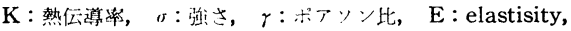
$\alpha:$ 比熱膨张係数

熱膨張は，アルミナ磁器よりやや大きく，マグネシア䂭 器より小さく，高沙まで異常膨张は涊められない（図 17).

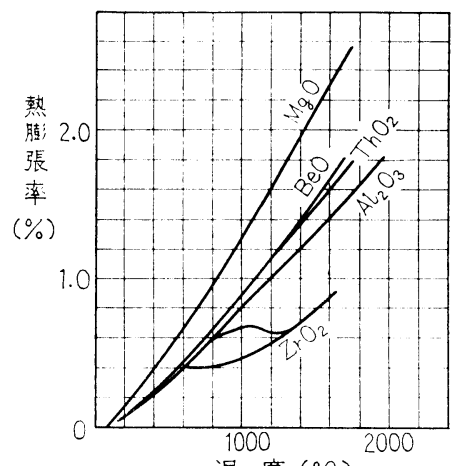

温 度 $\left({ }^{\circ} \mathrm{C}\right)$

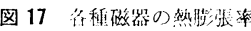

\section{2 電気 的性 質}

このよ5に，高い熱伝導棌にもかかわらずベリリア既 器の体積固有抵抗は，常滥では 1015〜10 $16 \Omega \mathrm{L}-\mathrm{cm}$ と大き

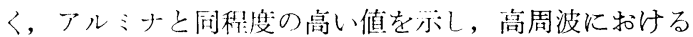
誘電体損失が袁わめて小さいのが特徽である（図 18〜 20).

\section{3 機械 的性 質}

ベリリア聯器の機械似强度はアルミナ磁器より少り, アルミナの約 $2 / 3$ 程度である。一般に高密度になるにつ れて強度は增すが，该器の持結晶粒経が粗大化すると強 度は抵下する，純度や製法により多少異なるが，硬度は 


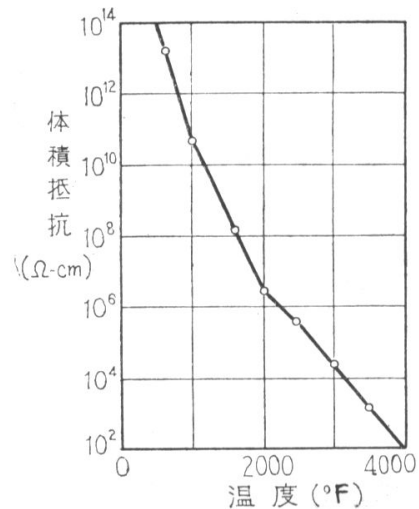

図 18 高純度ベリリフ磁器の体積抵抗

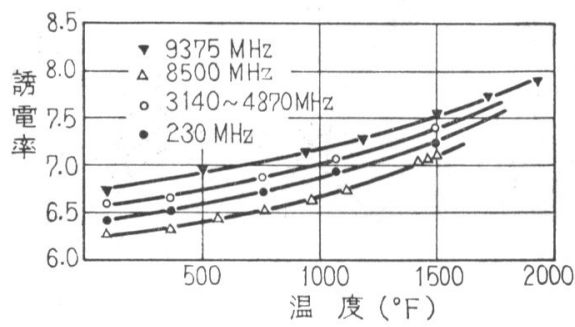

图 19 高純度ベリリア磁器の誘䉓率

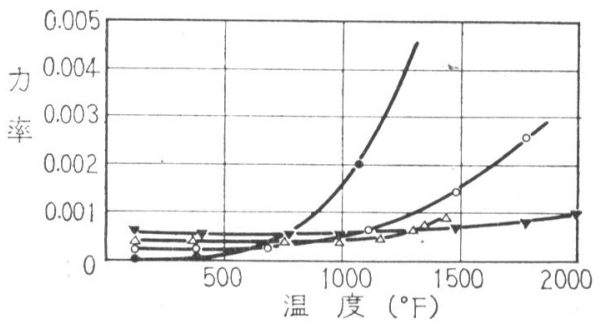

図 20 高純度ベリリア磁器の力率

モース 9 である。

\section{4 化学的性 質}

ベリリア磁器は, ふっ酸と反応し熱硫酸, 硝酸, 塩酸 に除々に侵される、溶融アルカリ，ピロりん酸塩はベリ

表 9 高純度ベリリアるつぼと各物質との反応性

\begin{tabular}{|c|c|c|}
\hline \multicolumn{2}{|c|}{ 種 } & 反 応 状 況 \\
\hline ガ ス & $\mathrm{H}_{2}, \mathrm{~N}_{2}, \mathrm{CO}_{2}, \mathrm{NH}_{3}, \mathrm{O}_{2}$ & 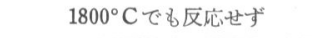 \\
\hline 金 & $\begin{array}{l}\text { Al } \\
\text { Pt, MO, Ni, W }\end{array}$ & $\begin{array}{l}\text { 高温 }\left(1500^{\circ} \mathrm{C}\right) \text { であ反応せず }(\mathrm{BeO} \\
\text { を遠元しない) } \\
\text { 高温でも反応せず }\end{array}$ \\
\hline & $\mathrm{Be}$ & 高温 $\left(1500^{\circ} \mathrm{C}\right)$ で使用可能 \\
\hline 属 & $\begin{array}{l}\mathrm{U} \\
\mathrm{Ti}, \mathrm{Zr} \\
\mathrm{Mg}, \mathrm{Na}, \mathrm{K}\end{array}$ & $\begin{array}{l}\text { 高温 }\left(1400^{\circ} \mathrm{C}\right) \text { であ反応せず } \\
\text { 高温でかずが応するが, きわめ } \\
\text { て緅温である. } \\
\mathrm{BeO} \text { を還元しない }\end{array}$ \\
\hline 酸化物 & $\mathrm{C}$ & $>1800^{\circ} \mathrm{C}$ で安定 \\
\hline そのほ & $\mathrm{ThO}_{2}$ & $>1800^{\circ} \mathrm{C}$ で安定 \\
\hline か & $\mathrm{ZrO}_{2}, \mathrm{MgO}, \mathrm{Al}_{2} \mathrm{O}_{3}$ & $>1600^{\circ} \mathrm{C}$ で安定 \\
\hline
\end{tabular}

リアを溶解するが，これ以外の塩類に対しては安定であ る. 水蒸気とは $1,300^{\circ} \mathrm{C}$ 以上の高温で反応するが, 真 空中では $2,000^{\circ} \mathrm{C}$ でも蒸発損失は認められない. 金属 では， $\mathrm{Nb}, \mathrm{Ti}, \mathrm{Zr}, \mathrm{Bi}, \mathrm{Si}$ とは高温で反応するが，溶 融 $\mathrm{Li}, \mathrm{Na}, \mathrm{Pb}, \mathrm{Ca}, \mathrm{Fe}, \mathrm{Ni}, \mathrm{Mo}, \mathrm{K}$ には耐食性を示 す(表 9 ).

\section{3. ベリリア磁器の用途}

以上の諸特性から各種の用途が開発され，アメリカで は電子工業用途はもらろん, 原子力関係分野の減速材, 核燃料マトリックスとして,ささら宇宙工学分野ではミ サイルや航空機の超高温部口ケット噴射口などの用途に 利用されて牤り，一方国内では電子工業用途が最も多 く, 特殊耐熱部品や, 近年では原子力用途や透明べリリ ア磁器を用いた高压 $\mathrm{Na}$ ランプの発光管材料として注目 されている。

\section{1 半導 体 基 板類}

$\mathrm{Ge}, \mathrm{Si}$ は最高使用温度が限定されているため, トラ ンジスタ，ダイオードなどの内部で発熱した熱の放散の 良否によって出力が著しく左右される. 電子機器の小型 化のためには, その放熱器の小型化が要求され, ベリリ ア磁器が絶縁抵抗が大きく，しかも熱伝導率が大きいの で，この種の小型化，高出力化の用途として最適であ り，各種の放熱板，放熱具が採用されている（図 21）。 また，パワートランジスタ用のヘッダーとして，従来の ガラスやアルミナ磁器と比較して, 著しく熱伝尊率や高 周波特性が良いため, ベリリア磁気のメタルシール品が 用いられている(図 22).

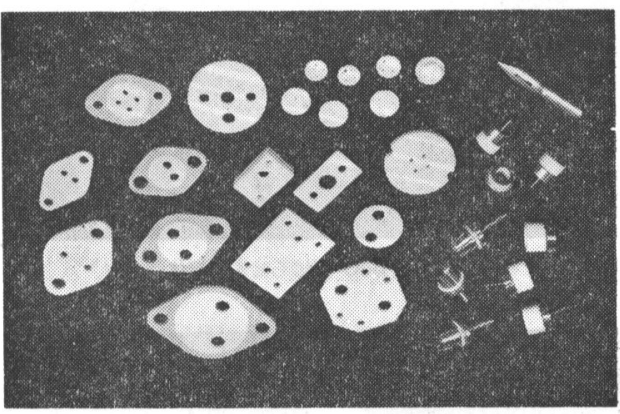

図 $21 \mathrm{BeO}$ 磁器放熱板

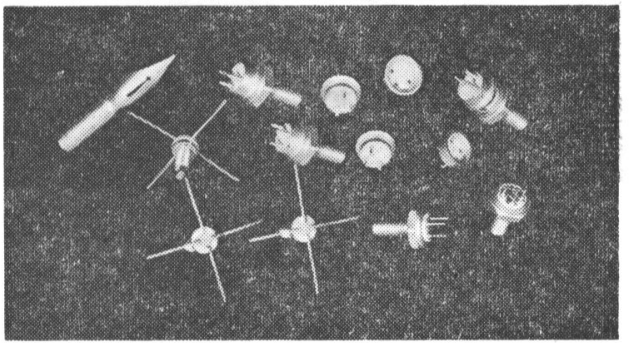

図 22 パワートランジスタ用 $\mathrm{BeO}$ 磁メタルシール品 


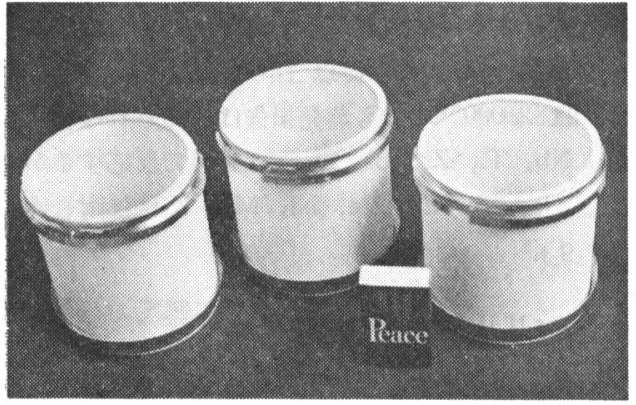

図 $23 \mathrm{BeO}$ 磁器クライストロンチューブ

近年 I.C 化の伸展が著しく，その基板材料として， ガラス，プラスチック，七ラミックか゚用いられている が, 機械的強度, 電気特性, 熱伝導率の点からみても, セラミック基板の利点が大きく，中でもベリリア基板は 高信頼性, 高出力, 高密度化された回路や LSI, MSI 用 基板材料として特に注目が集められている.

\section{2 クライストロンチューブやウインドー}

クライストロン空としては, 従来アルミナ磁器が用い られていたが，ベリリア磁器の高熱伝導性と高周波に特 ける誘電体損が小さいことから，高周波高出力管に用い られている.

\section{3 らせん支持体やレーザ用パイプ}

進行波管のらせん支持体としては，石英あるいはアル ミナ磁器が用いられていたが，乙だいに高周波，高出力 化されるにつれて, これらの材質では満足されなくな

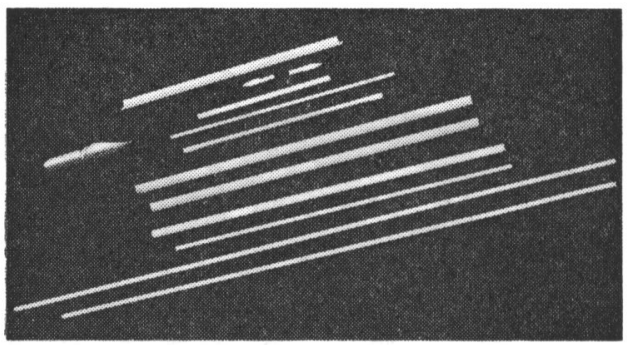

図 $24 \mathrm{BeO}$ 磁器らせん支持体

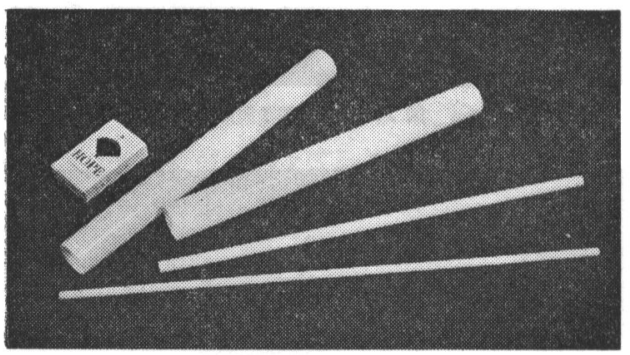

図 $25 \mathrm{BeO}$ 磁器レーザパイプ
り, ペリリア磁器が比較的加工性が良いことから, 丸棒 や角棒その他特殊形状のらせん支持体が採用されている （図 24）. 近年，レーザ光線による通信，医療，加工な どの応用研究が盛んであるが，ガスレーザ用の管とし て, 耐熱衝撃性が高く高伝導率, 耐熱性の特徵から, ベ リリア磁器に注目され採用されている(図 25).

\section{4 原子力用}

電気特性のほか耐熱性, 熱中性子吸収断面積が小さい ことから, 原子力用の減速剤や反射材として高純度べリ リア磁器が特に注目されている（図 26).

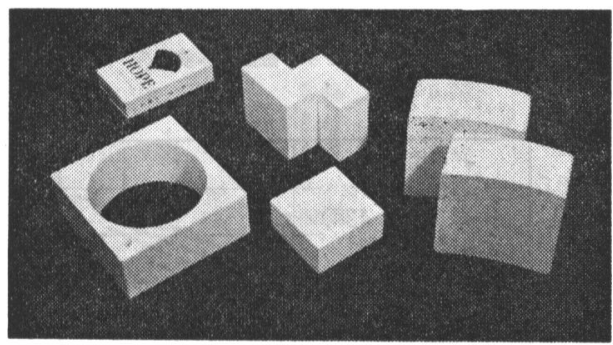

図 $26 \mathrm{BeO}$ 磁器原子炬用反射

以上ベリリア磁器の製法や用途, 特性について述べ たが，一部にベリリアの毒性について心配される場合も あるが，しかし一度焼結されたベリリア磁器の取り扱い や，そのメタライズ作業などでは，障害の心配は全くな いことを付記して特く.

参考文 献

(1) H. Pulfrioh, R. Wagner : U. S. pat 2163410(1939)

（2）ヘンリー，ジェイ,ノールト：特公告 昭26-6887

（3）ロバウト，エッチ，ブリストウ：特公告 昭 36 . 12767

(4) H. Pulfrich : 特公告 昭 36-6542

(5) R. J. Bondly : Electronics 20-7 (1947)

(6) C.S. Pearsall \& P. K. Zinger : Mass. Inst. Tech. Rept. No. 104

(7) James E. Beggs : IRE. Transaction on (1949), Component parts. (1957)

(8) J. Klamp \& Th. P. J. Botden : Philips Research Lob. (1965)

(9) E. Ryshkewitch : Oxicle cesamics (1960)

(10) J.W. Nersome at al : $\mathrm{Al}_{2} \mathrm{O}_{3}$ propecties, Technical paper No. 1 (Alumium Conp of Ancerica. 1960) 